Frest Fuld T Tre varus. 


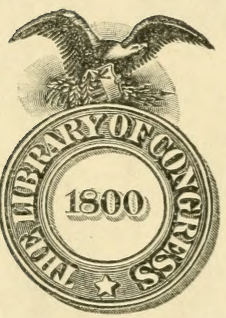

SI 421
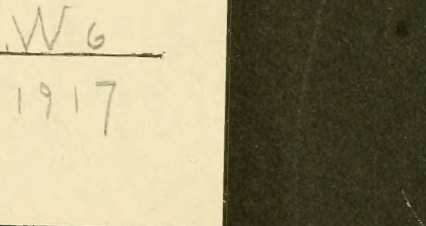


\title{
STATE CONSERVATION
}

\author{
SD 421 \\ .W6 \\ 1917 \\ WISCONSIN
}

Copy 1

\section{Forest, Field and Marsh Fire Laws}

\author{
with
}

Instructions to Town Chairmen, Road Superintendents, Rangers

\section{and Patrolmen}

MADISON, WIS.

1917 


\section{D. of D. \\ FEB 251918}




\section{FOREWORD}

This pamphlet is issued for the benefit and information of such persons or officials who are to a greater or less extent interested in the Wisconsin laws relating to forest, field, swamp, marsh and other running fires. It is intended to briefly present such provisions as may be of particular interest to the different classes of citizens.

To Town Chairmen and Road Superintendents.

Read this booklet carefully. Each town chairman by provision of law is, town fire warden, and each road superinendent is assistant town fire warden to the chairman. Under the law you are duty bound to fight such fires and when you are notified of a fire or receive a call for assistance, YOU MUST ACT IMMEDIATELY, irrespective of what work you may be engaged in when you receive such notice or call for assistance.

You have the power of sheriffs to arrest without warrant for any violation of the fire laws. You have the power to demand the assistance of any able-bodied male citizen to help fight fires.

FARMERS AND SETTLERS must not start fires during dry periods. Before burning your brush talk the matter over with either your town chairman or with a road superintendent; these men under the law are town fire wardens. Always help willingly and promptly when called upon to fight fires. 
You cannot tell what day you may wish the help of your neighbors to save your own home from fire. Do not start back fires until absolutely necessary.

Payment of fire fighters (see sec. 2613.)

Town chairmen and road superintendents will be paid such a wage for fire fighting as may be determined upon by the town board. All men called out by the fire wardens shall receive not more than twenty cents $(20 \mathrm{c})$ per hour for the time actually employed, which compensation is also to be paid by the town board. 


\section{INSTRUCTIONS TO FIRE FIGHTERS}

If you discover a fire too large to be put out at once, get help immediately. If necessary, notify the nearest fire warden, or patrolmen, or if neither is available any sheriff or deputy sheriff of the county who should notify the fire warden.

Organize and select the best man as leader. When a fire-warden is present he should take charge.

Form a plan of action and stick to it. Consider the rights of property owners, but do not let them back fire to protect their own property unless it will be for the genera: good. Back fires should be authorized only by the man in charge.

If you believe that a fire will take a considerable time to put out, divide your force into crews, one to relieve the other. Keep some one on the job all the time.

The best tools for fighting fire are the shovels, mattock, ax and wet sacks. Rakes, hoes and brush hooks are also useful.

Sand or earth thrown on a fire is as effective as water.

If possible stop the fire by means of a trail or trench. Where the fire burns slowly in open timber pinch it out by knocking the burning material back into the burned area. Put out logs and stumps by throwing dirt on them. Never leave burning trees or snags near the fire line. Many fires well under control have broken out again when a little 
additional work would have made them quite safe.

Work at night or in the early morning, instead of by day, when it is possible. At night a six-inch trail will often hold a fire that would leap a quarter of a mile during the heat of the day. At night less time is wasted carrying water to the fire fighters.

Fires occurring in dense brush or thickets may require back firing. Start your back fire far enough in front so that you will have time to complete your work before the main fire reaches you. Start it from a road, trail or stream if possible. If not, cut a trail, scrape it clean, light your fire and guard your trail.

Back fire along the top or bottom of a ridge rather than half way up the slope.

See to it that the ends of your back fire are safe. Run them together if possible, thus surrounding the main fire, or else run them into portions that have burnt out, or to a stream or road. A back fire is just as dangerous as the original one unless it is perfectly safe throughout its whole length.

Watch the fire line after the fire is under control. Sparks blown from burning snags, chunks thrown from falling trees, and many other things may cross the fire line. Keep some one on guard.

Use your best judgment in fighting fires when you are in charge as local conditions make it impossible to give any iron clad rules to follow. If some one else is in charge obey his instructions.

Lumber Companies-All lumber companies operating steam railroads must equip their engines with the best fire fighting parapher- 
nalia possible and the following suggestions are made for this equipment and means of combatting fires:

(1) Proper stacks and screens. (2) Barrels of water along steep grades, at intervals, where there are no streams of water that have a steady flow in dry weather. Equipment for all engines, such as hose and all attachments necessary to handle water quickly and efficiently, to extinguish fires which start along the railroad. (4) Water tank car for emergencies. (5) A patrol should be made after all trains in dry weather. (6) A careful inspection should be made at regular periods of all equipment. (7) Instructions should be issued to all section crews and employees to be on the lookout for fires and just what they should do toward extinguishing same. (8) All inflammable material should be removed from along tracks for at least fifty feet on either side.

Railroads-All of the above rules that are practical and possible of enforcement should be used by main line railroads as well as the logging railroads. If the proper officials of all railroads will issue written instructions to their employees to carry out the provisions of the forest laws applicable to railroads a tremendous improvement can be made and many fires averted. Trackmen should be instructed to clean all rights of way at least twice per year of inflammable material. Sufficient trackmen should be kept to promptly put out any fires that may occur along the rights of way. All locomotives should be equipped with proper screens to prevent the escape of sparks and hot cinders and with adequate devices to prevent the escape of fire from ash 
pans, and a proper inspection should be made of all such devices at short intervals during the dry weather in both spring and autumn. Instructions should be issued to all engineers, conductors and all employees to report fires to the railroad agents as is required by law.

Persons Burning Brush-Before burning brush or clearing land, notify the fire warden. Burn brush in still weather or when the breeze is away from adjacent timber and towards open land. If possible, the best time is in cloudy weather just before a rain storm.

If there is a lookout station in your vicinity notify the lookout watchman so that he will know that you are going to burn your brush, as otherwise he will likely go to the trouble of summoning men to fight what he takes to be a forest fire. Always have plenty of persons close around when burning brush so that in case this fire escapes and gets into woodland you will be able to extinguish it.

Campers, Hunters, Fishermen, Etc.-Be careful of your campfire. Never build your campfire larger than is needed, rake leaves and dry wood away from it, and in windy weather dig a shallow hole for it. Never build a fire against hollow logs or trees where it will be hard to extinguish. Never leave camp until you have entirely extinguished the fire with water.

Be careful with matches, cigar or cigarette stubs and burning tobacco and never throw them where there will be any chance of them igniting leaves or wood.

Rural Mail Carriers-The post office department of the United States government has requested all rural and star route carriers to 
notify the proper authorities when they discover a fire along their route, and fire warden should use every means to secure their hearty cooperation along this line.

Any suggestion as to a possible way to better the system will be given the most careful attention when sent to the commission. 


\section{LAWS RELATING TO}

\section{Marsh, Swamp, Field and Forest Fires.}

\section{Chapter 282 Laws of 1917.}

Lssued by the Wisconsin State Conservation Commission.

State and Local Fire Wardens. (SECTroN 26.11) The commission shall be in charge of and give suitable directions to the entire fire warden force of the state. The chairman of the town board of each town in the state shall be the town fire warden for such town and the superintendents of highways for the different road districts within the different towns shall be assistant town fire wardens for their respective towns.

Powers of Conservation Commission. (SForion 26.12) The commission shall have general charge of the fire warden force of the state, and shall have authority to mass such fire warden force as may be available at any special point to suppress fires. In cases of emergency, or when the town shall have no highway superintendents, or the town shall be unusually large, the commission may on recommendation of the town chairman, appoint, temporarily, needed fire wardens, whose duties and authority shall be the same as herein provided for town and assistant town fire wardens. 


\section{Duties of Fire Wardens; Police Powers; Com-}

pensation and Rewards; Taxation and Payment. (SEctrox 26.13) (1) Each fire warden before entering upon his duties, shall take an oath of o.Tice and file the same with the commission. All fire wardens shall take prompt and effective measures against the spread and illegal setting of forest, field, marsh or swamp fires within their towns and districts and shall have the power of sheriffs to arrest without warrant for violations of the provisions of any sections of the statutes relating to setting, failure to extinguish, or care of fires. They shall have authority to call upon any able-bodied citizen, in territory in which they act, to assist in extinguishing forest, marsh. swamp and other running fires in such manner as they may direct.

(2) Those assisting either the town or assistant town fire wardens in the extinguishing of forest, marsh, swamp and other fires shall receive compensation for their services at not more than trenty cents (20c) per hour for the time actually employed. The commission is authorized to approve for payment not to exceed fifty per cent (50\%) of the clear proceeds of any fine collected in an action brought for a violation of any of the provisions of sections 4405 a to 4406 of the statutes relating to setting, failure to put out or care of fires, where the evidence to secure a conviction is furnished by a town fire warden, an assistant town fire warden, or any other person.

(3) No payment shall be made to any claimant under this section until he shall 
have presented an itemized account and made oath or affirmation that said account is just and correct, which account shall be audited and approved by the town board. The town board shall thereupon direct the town clerk to issue a warrant upon the town treasurer for the sum to which such claimant is entitled, and the town treasurer shall pay the same.

(4) Expense borne by road districts of Towns. The expense of preventing or extinguishing forest, marsh, swamp or other rumning fires by the town or assistant town fire wardens, and by those called upon by either of said fire wardens to assist them, shall be horne by the road district or districts within which the expense was incurred, and the superintendent of highways of each road district, or if there is no such road superintendent then the town board, may levy and assess a tax for defraying such expense. Such tax shall be collected in the same manner as other taxes, and such tax when so collected shall be paid into the town treasury from which such expense is paid.

Payment of Fire Wardens Appointed by the Commission. (Section 26.14) (1) Each fire warden appointed by the Commission to act in case of emergency, shall receive for his actual services rendered, two dollars (2.00) per day, one-half of which shall be paid by the county where such service is performed, and one-half by the state; and any employee engaged by the commission or by any fire warden appointed by the commission, to assist in preventing or suppressing forest, swamp, marsh or other running 
fires shall receive for such servicos not mor than twenty cents $(20 \mathrm{c})$ per hour, and said expense shall also be paid, one-half by the county where such service is performed, and one-half by the state.

(2) The fire wardens appointed by the commission shall prepare itemized accounts for their own services and the services of their assistants, and no such account shall be paid until it has been approved by the commission. The secretary of state shall not issue warrants for more than ten thousand dollars $(\$ 10,000.00)$ for fighting forest fires in any one county in any one year, and onehalf the amount pair by the state shall be refunded to the state by the county, in which the fires were fought. In case the work or fighting fires covers a portion of two or more counties, the amount to be paid by each county shall be decided by the commission.

(3) As soon as any account has been pairi by the state treasurer, the commission shall send to the proper county treasurer a bill for the county's share of the expenses and a copy of the bill shall be filed with the secretary of state. The county shall have sixty (60) days within which to pay such bill, but if not paid within that time, the county shall be liable for interest at the rate of six per centum $(6 \%)$ per anmum. If said sixty days shall have elapsed without payment before the time provided by law for the secretary of state to certify to the counties the levy for state taxes, he shall include an amount sufficient to pay such bill as a part of the levy against the county for state taxes. 
Liability of Town Fire Wardens and Citizens. Sectrox (26.15) Any fire warden who shall refuse to carry out the provisions of section 26.13 or any able-bodied citizen who shall refuse to render assistance as provided by said section, shall be punished by a fine of not less than ten $(\$ 10)$ or more than fifty $(\$ 50)$ dollars, or by imprisonment in the county jail for not less than ten (10) or more than thirty (30) days, or by both such fine and imprisonment.

Posting Fire Warning Notices. Section (26.16) Each town fire warden and assistant town fire warden shall post or cause to be posted conspicuously in those parts of his town or district where fires are likely to occur, all notices furnished him for that purpose by the commission.

Reports by Fire Wardens. Section (26.17) Every assistant town fire warden, immediately after each fire within his district shall forward to the commission and to the town fire warden a detailed report of said fire. The town fire warden shall report to the commission, annually, on or before the first day of December, a summary of all forest fires within their towns or districts during the year and such other matters as the commission may direct..

Note.-The words "assistant town fire warden" mean the ROAD SUPERINTENDENT. The words "town fire warden" mean the TOWN CHAIRMAN. The word "commission" means the State Conservation Commission. 
District Attorneys to Prosecute. SHa TIOS (26.18) Whenerer an arrest shall have been made for any violation of any provision of this chapter, or whenever any information of such violation shall have been lodged with him, it shall be the duty of the district attorney of the county in which the criminal act was committed to prosecute the offender or offenders. If any district attorney should fail to comply with the provisions of this section he shall be guilty of a misclemeanor and upon conviction shall be fined not lass than $\$ 100$ nor more than $\$ 1,000$, or be imprisoned not less than 30 days nor wenre than one year, or both in the discretion of the court. The penalties of this section shall apply to any magistrate, with proper authority, who refuses or neglects without cause to issue a warrant for the arrest an.l prosecution of any person or persons when complaint, under oath, of violation of any terms of this chapter has been lodged with him.

\section{L.WWS RELATING TO SETTING ON FRES.}

Destruction of Warning Notices. SEctrox (26.19) Any person who shall maliciously or wilfully destroy, deface, remove or disfigure any sign, poster or warning notice posted under the provisions of this chaptor sinal be guilty of a misdemeanor and punishable upon conviction by a fine of not less than $\$ 15$ nor more than $\$ 100$, or by imprisuninent in the county jail for a period of not les. than ten days nor more than three monthe, of hy both such fine and imprisonment. 
Town Boards Can Forbid Setting of Fires. SEcrion $(4405 a)$ (1) Whenever the town board of any town deems it imprudent to set fires upon any land within the town or district they shall post or cause to be posted notices in five public places in each township in such town or district forbidding the setting of fires therein, and after the posting of such notices no person shall set any fire up u any land in said town or district, except for warming the persen or rooking food, until written pernission has been received from one of the fi:"e wardens of said town.

\section{(2) Camp lires Must be Extinguished.} All persons who start camp fires upon any land in this state shall exercise all necessary precautions to prevent damage therefrom, and shall entirely extinguish the same before leaving tisem. Every person violating any provision of this section shall be punislsed by a fine of not less than ten nor more tian fifty dollars, or by inprisonment in the county jail not more than six months for each offense.

I iability of Persons who Build Fires. SECTrox (4406) Any person who shall build a fire on any lands in this state not his own or uncler his control, except as hereinafter provideci, shall before leaving the same, totalis atinguish it, and upon failure to do so silull be punished by a fine not exceeding $\$ 100$ or by imprisonment in the county jail not ${ }^{2} x-$ (ceding one month, or by both such fine and imprisonment. Any person who shall negligently or wilfully set fire to or assist another to set fire on any land. whereby such 
land is injured or endangered or shall wilfully or negligently suffer any fire unon his own land to escape beyond the limits thereof, to the injury of the land of anoticer. shall be punished as heroinbefore providnd and be liable to the person injured for all damase that may be caused by the fire

\section{LAWS RELATIG TO RALROADS.}

Liability of Railways for Damages Caused by Fire. Sectiox (1816a) (1) Each railroad corporation owning or operating a railroad in this state, shall be responsible in damages to every person and corporation whose property may be injured or destroyed by fire communicated directly or indirectly by locomotive engines, in use upon the railroad owned or operated by such railroad corporation, or by the burning of grass, weeds or rubbish on right of way by employes of such corporation, and each such railroad corporation shall have an insurable interest in the property upon the route of the railroad owned or operated by it, and may procure insurance thereon in its own behalf for its protection against such damages.

(2) Whenever the property owned by any person or corporation shall be injured or destroyed by fire communicated by locomotives in use upon any railroad owned or operated by a railroad corporation, or by the burning of grass, weeds and rubbish on the right of way by employes of such corporation, so as to render the railroad corporation liable, under subsection 1 of this section, or otherwise, the owner of such property injured or destroyed may recover damages for s!lch loss, 
and to recover the same it shall only be necessary for him to prove the loss of or injury to his property, and that the fire originated in the manner hereinbefore stated. If such corporation fails or neglects $\omega_{i}$ ) pay such damage within sixty days after notice in writing that a loss or injury has occurred. accompanied by an affidavit thereor, served upon any officer or station or ticket agent employed by such corporation in the county where such loss or injury occurred, such owner shall be entitled to recover from the corporation double the amount of damages actually sustained by him in any court of competent jurisdiction. If such company shall, within sitxy days, offer in writing to pay a fixed sum, being the full amount of the dlamages sustained, and the owner shall refuse to accept the same, then in any action thereafter brought for such damages, when such owner recovers a less sum as damages than the amount so offered, then such owner shall recover only his damages, and the railway company shall recover its costs.

\section{Spark Arresters on Engines, Boilers and} Iogging, Locomotives. SEction (26.20) (1) Between Narch 1 and November 1 it shall be unlawful for any logging locomotive, donkey, traction or portable engine, and all other engines, boilers, and locomotives, except railway locomotives operated in, through, or near forest, brush, or grass land, which do not burn oil as fuel, to be operated without a screen or wire netting on top of the smokestack and so constructed as to give the most practicable protection against the escape of sparks and cinders from the smokestacks 
thereof, and each such engine shall be prorided with the most practicable derices to prevent the escape of fire from ash-pans and fire boxes. The term logging locomotive as used in this act shall be construed to mean any locomotive operated on a railroad branch, line, or division, the chief or main business of which is the transportation of logs, lumber, or other forest products.

(2) Spark Arresters on Locomotives other than Logging Locomotives. All locomotives operated on any railroad other than a logging railroad shall be equipped with the most practicable spark arresters so constructed as to give the greatest possible protection against the escape of sparks and cinders from the smokestacks thereof, and each such engine shall be provided with the most practicable device to prevent the escape of live coals from ash pans and fire hoxes, and said devices between March 1 and November 1 shall at all times be maintained in goor repair. It shall be the duty of the superintendent of motive power or equivalent officer of each such rairroad to designate an employe of such railroad at each division point and round house who shall examine each locomotive each time it leaves the division point or round house between March 1 and November 1 , and such employe shall be held responsible for the proper carrying out of the provisions of this section, but without relieving the company from its responsibility hereunder.

(3) Locomotive Inspector: Powers. Any locomotive inspector designated by the conmission shall have the power to reject from service immediately any locomotive, donkey, 
traction, or portable engine which, in the opinion of the said inspector, is deficient in adequate design, construction, or maintrnance of the fire protective devices designated in subsections (1) and (2) of this section, and any such locomotive, donkey, traction or portable engine so rejected from service shall not be returned to service until such defects have been remedied to the satisfaction of said locomotive inspector. In case of disagreement between said inspector and the owner of the lccomotive, donkey, traction, or portable engine so rejected from service as to the efficiency or proper maintenance of said protective devices, then the owner of said locomotive, donkey, traction, or portable engine may appeal to the railroad commission of Wisconsin for a decision of said matter, but pending such decision the said locomotive, donkey, traction, or portable engine shall not be returned to service.

\section{(4) Cleaning Railway Rights of Way.} Every corporation maintaining and operating a railway shall, at least once in each year, cut and burn or remove from its right of way all grass and weeds and burn or remove therefrom all brush, logs, refuse material, and debris within a reasonable time, and whenever fires are set for such purpose, shall take proper care to prevent the escape thereof from the right of way.

\section{(5) Depositing Fire or Ashes on Tracks.} No such corporation shall permit its employes to deposit fire, live coals, or ashes upon their tracks outside of the yard limits, except they be immediately extinguished. 
(6) Reporting Fires on Rights of Way. Engineers, conductors, or trainmen who discover that fences or other material along the right of way or on lands adjacent to the railroad are burning or in danger from fire, shall report the same to the agent or person in charge at their next stopping place at which there shall be a telegraph station. Corporations maintaining and operating railways shall give particular instructions to their section employes for the prevention and prompt extinguishment of fires, cause notices, which shall be furnished by the state forester, to be posted at their stations, and when a fire occurs along the line of their road, or on lands adjacent thereto, for which fire they are responsible, they shall concentrate such help and adopt such measures as shall most effectually arrest its progress.

\section{(5) Wire Patrol. All such corpcrations} during a dangerously dry season, and when so cirected by the commission, shall prori fire patrols for duty along their tracks. Whenever said commission shall deem it necessary it may order such corporations to provide for patrolmen to follow each train throughout such districts as may be necessary to prevent fires. When said commission has given a corporation such notice that in its opinion the conditions require such patrol after trains, the corporation shall immediately comply with such instructions throughout the districts designated; or on its failure to do so, said commission may employ patrolmen, and furnish them with the necessary equipment to patrol the rights of way of such corporations, and the expense of the 
same shall be charged to the corporation and the same may be recoverable in a civil action in the name of the state of Wisconsin, and in addition thereto, the said corporation shall be deemed guilty of a misdemeanor. It is also made the duty of such corporation, acting independently of such commission, to patrol its rights of way aiter the passage of each train when necessary to prevent the spread of fires and to use the highest degrees of diligence to prevent the setting and spread of fires, and it is also made the duty of its officurs and employes operating trains in this state, to use diligence in the extinguishmeni of fires set by locomotives or found existing upon their respective rishts of way, and any bealigence in this regard shall render such corporation or any officer or employe lhereof guilty of a misdemeanor.

(8) Inspection and Fntry. The commission is authorized to inspect or cause to bre inspected any locomotive. donkey, or threshing ensine. railway loenmotive, and all other encines, boilers. and locomotives operater in, through or near forest, brush, or arass land and to enter upon any property for such purpose, or where they may deem it necessary in order to see that all the provisions of this act are duly complied with.

(9) Penalty. Any corporation by its officers, agents, or employes, wilfully violating the provisions of this section, shall be liable to a penalty of not less than $\$ 50$ nor more than $\$ 500$ for each and every such riolation, to be collected in a civil action in the name of the state. 
In cuse the commission and any colporation or individual operating any locomotive. donkey. or threshing engine. of any onfine. boller. of locomosite cantur atyer as to the most practical devioe or devices for nowent=

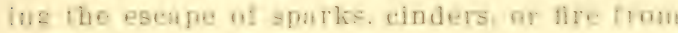
rmokestanks. ash puns or fire buxes. then 3he Eume shall be determines by the railroad comnission of Wisconsin.

(1) Rveuption. The nonumiston gholl be re the nower to fanmpt irom the provisions of subsections (1), (2), (3), and (4) of this swotion ang railroad. when. In tre julgment mombitione alomg the right of wat are enel that the moluend hamari ronibre woth broiective devices unnecessary.

Penalty. Secriox (4406a) Any person wilfully falline to eomuly with ans of lliw tequiremente of aection 26. 20 shall be seemed fuilts of a mishemeanor and yhall be punished. upon conviction. by if num of um less than 850 nor more than \$500. or by imprisonnont in the eounty fuil not wxcowdinc one yratr. or by both such fine and impritunment. .

\section{Liabilits of Railway fur Damage rauserl} by Fire. ismox 20.21 , In addition to the funaltime provided in the preceding yection -6.30, the United States, the state. the county or private owners, whose property is injured or destroyed by such fires. may recover, in a ciril action. double the amount of damagea suffered. if the fires occurred throueh wil. inlness, malice or neeligence. Persons or eorporations causing fires in violation of this 
chapter shall be ilable to the state in an action for debt, to the full amount of all damages done to state lands and tor all expenses incurred by the towns fighting said fires. 

LIBRARY OF CONGRESS

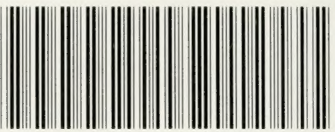

0000897553 A 


\section{LIBRARY OF CONGRESS |||||||||||||||||||||||||||| 0000897553 A}

